\title{
THE BRITISH COUNCIL
}

$\mathrm{T}$ HE feature article which accompanies the general survey of the year in the British Council's annual report*, 1960-61, deals with the English language abroad. An introduction by Lora Bridges comments on three characteristics of the Council's work as a whole: the change in the nature of the duties of the Council's staff which has led to their work becoming more professionalized; the extent to which most of the Council's work depends on close co-operation with other people; and the measure to which the tasks undertaken by the Council in countries overseas depends on what the country concerned is most anxious the Council should do. The teaching of English is one of the four main tasks of the Council, and this article sets forth the nature of the problem which this presents and some of its implications, as well as the specific functions and responsibilities of the British Council.

The general survey of the year directs attention to a particular aspect of British education overseas which is not covered in the feature article-the assistance provided to overseas schools, for which additional funds were used in 1960-61. Seventy-seven posts in schools abroad, including eight headships, were filled during the year, and this recruitment work is expected to increase as the scheme for educational co-operation in the Commonwealth is carried through. Aid was also increased to schools in Latin America, and a first call on the new funds was for urgently needed increases in the emoluments of British teachers.

The Council's responsibilities for visitors and students from overseas in Britain continue to grow, and it is estimated that there are now more than 55,000 such students and trainees at universities and technical colleges in the United Kingdom or in schemes of apprenticeship and training. Some 10,660 students were met on arrival, of whom 3,082 were from Commonwealth countries and 5,922 from Colonial territories. Permanent accommodation was arranged for 343 in Council residences and for 4,634 in lodgings, while transit accommodation in Council residences on first arrival was arranged for 2,399 . Accommodation in university halls of residence was arranged for 609 , and 10,539 offers of hospitality made through the Council were accepted. Holiday courses of 7-15 days' duration were attended by 2,298 , and week-cnd courses, study visits and surveys

* The British Council. Annual Report, 1960-1961. Pp. vi+114+ 8 plates. (Iondon: The British Couneil.) 2s. 6d. net. by 11,765 , while 3,282 attended on arrival short introduction courses arranged by the Council or by colleges and institutions in collaboration with the Council. With the further $£ 3$ million to be provided by the Government to increase the accommodation and welfare services available for overseas students and trainees, it is hoped to provide some 5,000 additional hostel places, while there are also plans to expand the social and cultural centres for them in London and certain other cities.

In 1960-61, 170 Commonwealth Scholars came to the United Kingdom. Awards were made for one short visit to the United Kingdom for consultation or lectures and eleven such visits to other countries; 65 awards of travel grants were made for interchange visits of university teachers between the United Kingdom and other Commonwealth countries, while there were 119 short visits by senior members of university staffs betweon the United Kingdom and foreign universities as well as four longer visits and 79 interchange visits of younger research workers. Of 341 specialist tours, advisory visits and delegations of British specialists overseas, 197 were to Central and Eastern Europe, 74 were in education, 68 in medicine, 56 in science and technology, and 39 in social science, while the Council also provided a full range of welfare services for the $35 \mathrm{I}$ teachers who secured places in university departments and institutes of education and at teacher training colleges under the Commonwealth Teacher Training Bursary Scheme. Under the United Nations specialized agency schemes, the Colombo Plan, the technical assistance schemes for Yugoslavia, Ghana, Nigeria, and the programmes of the Central Treaty Organization and the Foundation for Mutual Assistance in Africa, 1,574 fellows, scholars and trainees were administered by the Council, as well as 253 visitors from 23 countries under the United States Third Country Training Scheme. In all, 367 Council scholarships were awarded, and exchanges under the Anglo-Soviet Agreement amounted to 400 visitors each way. Reference is also made to the rapid growth of the United Nations International Atomic Energy Fellows scheme, under which some 60 have come to Britain in each of the past two years, and to the regular supply of books to 176 libraries throughout the world, of which the Council directly controls 116, supplying also 276 periodicals, and 989 specialized periodicals to 169 other institutions.

\section{THE HUMAN SCIENCES IN INDUSTRY}

W HILF many firms call in technical experts to advise them on some new equipment they are planning to install, or on problems that arise in the operation of existing plant, comparatively few consider the possibility of seeking advice on problems concerned with the men and women who operate the machines or run the plant. Yet the importance of the human factor is being increasingly recognized. Increasing mechanization, although it has changed the nature of the human contribution, has by no means diminished its importance. When machines become more complex to operate and maintain, it is often the capacity of the human operator rather than of the equipment that places the limit on the productivity of the man/machine team.

Why does only a small minority of firms recognize the value of research on human performance as an essential feature of industrial development? They are, perhaps, unaware of how the results of research can be applied to the solution of human problems in industry, and how, if applied early enough, they can help to prevent new problems arising. It is in the 